УДК 338.435:316.343.37(477)

(C) 2015

Дворник I. В., аспірант

(науковий керівник - доктор економічних наук, професор М. П. Талавиря)

Національний університет біоресурсів і природокористування України

\title{
РОЛЬ ТІНЬОВОЇ ЕКОНОМІКИ У ФОРМУВАННІ ДОХОДІВ СІЛЬСЬКОГО НАСЕЛЕННЯ
}

\section{Рецензент - кандидат економічних наук 3. Д. Овчарик}

У статті досліджено основні прояви тіньової економіки в прочесі формування доходів сільського населення. Основними джерелами незадекларованих доходів є: заробітна плата «в конверті», надання послуг, продаж сільськогосподарської продукиії на ринку. Представлено схеми використання «білої», «сірої» та «чорної» заробітних плат, а також принципова модель підпільної економіки. Запропоновано системи заходів з боку держави щуодо підтримки сільського населення та контролю ведення тіньової діяльності роботодавиями.

Ключові слова: доходи, сільське населення, тіньова економіка, заробітна плата, ринок.

Постановка проблеми. Визначення обсягів тіньових доходів залишається однією 3 найактуальніших проблем дослідження доходів сільського населення України. Весь тіньовий сектор економіки сягає 40-50 \% ВВП (на думку експертів, цей рівень можна вважати нижньою межею). Вітчизняна специфіка тіньових процесів є досить унікальною, адже первісне нагромадження капіталу, яке в інших країнах відбувалося за кількох поколінь, у нас пройшло за кілька років.

Аналіз останніх досліджень і публікацій, у яких започатковано розв'язання проблеми. Проблемами тіньової економіки займалися такі науковці: О. В. Мороз, В. М. Семцов, [7] В. І. Авдійський, В. А. Дадалко [1] та інші. Проте без проведення комплексних досліджень тіньових економічних відносин неможливо сформувати принципи раціональної системи заходів гарантування безпеки 3 метою боротьби та локалізації тіньових процесів.

Мета досліджень - визначити основні прояви тіньової економіки у формуванні доходів сільського населення.

Завдання досліджень - визначити основні джерела виникнення та структуру незадекларованих доходів сільського населення, запропонувати напрями їх детінізації.

Матеріали і методи досліджень. Теоретикометодологічною основою роботи є діалектичний метод пізнання. Крім цього, були застосовані як традиційні методи економічних досліджень, так i специфічні: монографічний (вивчення практичних аспектів формування доходу сільського населення), балансовий (оцінка впливу особистого господарства на рівень життя населення), метод експертної оцінки (визначення впливу внутрішніх i зовнішніх факторів). Інформаційною базою дослідження $€$ законодавчі акти, нормативноправові документи; статистичні матеріали Державного комітету статистики України; результати анкетування; матеріали досліджень вітчизняних та закордонних авторів.

Результати досліджень. Тіньова економіка це не обліковувана офіційною статистикою діяльність, яку свідомо приховують від державних органів 3 метою ухилення від сплати податків та адміністративних процедур. Тіньові доходи формуються за рахунок прихованих: оплати праці найманих працівників, змішаного доходу підприємців і доходу від власності. Серед економістів побутує думка, що тіньова економіка, особливо в періоди економічних потрясінь, може відігравати навіть позитивну роль (окрім незаконності), адже вона робить усе те, що й офіційна, i, як правило, більш ефективно: створює нові робочі місця, піднімає платоспроможність населення, збільшує оборот товарів і послуг. Проте для держави вона є негативним явищем: суб'єкти господарювання не сплачують податків і внесків на соціальне страхування, тому вона створює значні проблеми для уряду й не гарантує соціального захисту для сільського населення.

Найбільшу частку в структурі доходів сільського населення за даними Державної служби статистики України становить заробітна плата [10]. Органи влади проводять активну роз'яснювальну роботу серед населення, роботодавців, юридичних осіб щодо дотримання законодавства під час декларування праці, сплати податкових зобов'язань. Проте ситуація щодо легалізації заробітної плати корінним чином не змінюється. Тому, виходячи з форм виплат заробітних плат працівникам, зокрема тінізації останньої, в економічній літературі та побуті застосовують такі 
терміни, як «біла», «сіра» та «чорна» зарплати.

Використання прозорих механізмів розрахунку з працівниками забезпечує законне проведення оплати праці, що є традиційним зокрема для державних підприємств. У таких випадках застосовується «біла» заробітна плата (рис. 1).

У разі використання «білої» заробітної плати фінансові та правові відносини між роботодавцем і працівником обумовлені й зафіксовані, у повній мірі регулюються Кодексом законів про працю України. [4] «Біла» зарплата істотно спрощує процедуру отримання кредиту, оформлення візи, закордонного паспорта, а також це оплата відпус- ток, лікарняних, надання різних пільг, відповідна пенсія тощо.

Аналізуючи «сіру» зарплату, спостерігається наступна ситуація (рис. 2).

«Сіра» зарплата - це коли працівник офіційно оформлений на підприємстві й навіть отримує певну суму заробітної плати в бухгалтерії. Але основна частина такого заробітку - «в конверті» ніде не зафіксована. Це означає, що соціальні виплати будуть оплачені за мінімальним тарифом.

«Чорна» зарплата $є$ повною протилежністю «білої» (рис. 3).

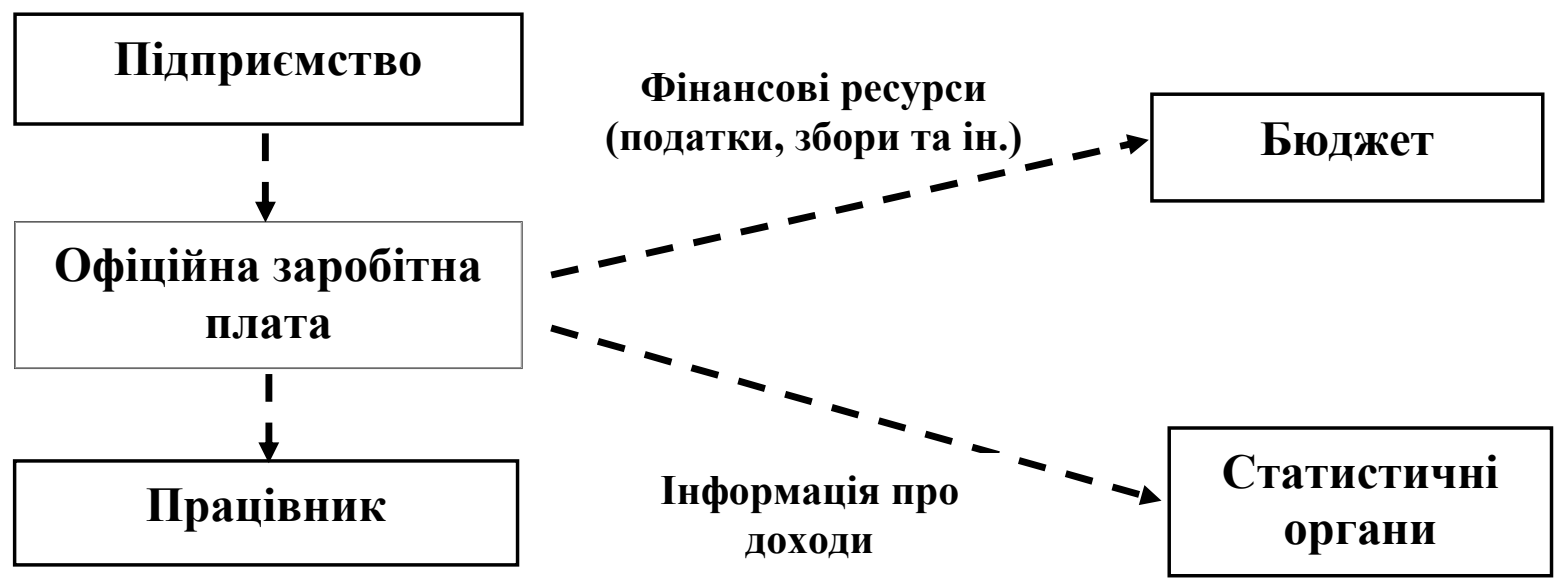

Рис. 1. Схема використання «білої» заробітної плати

Джерело: власні дослідження

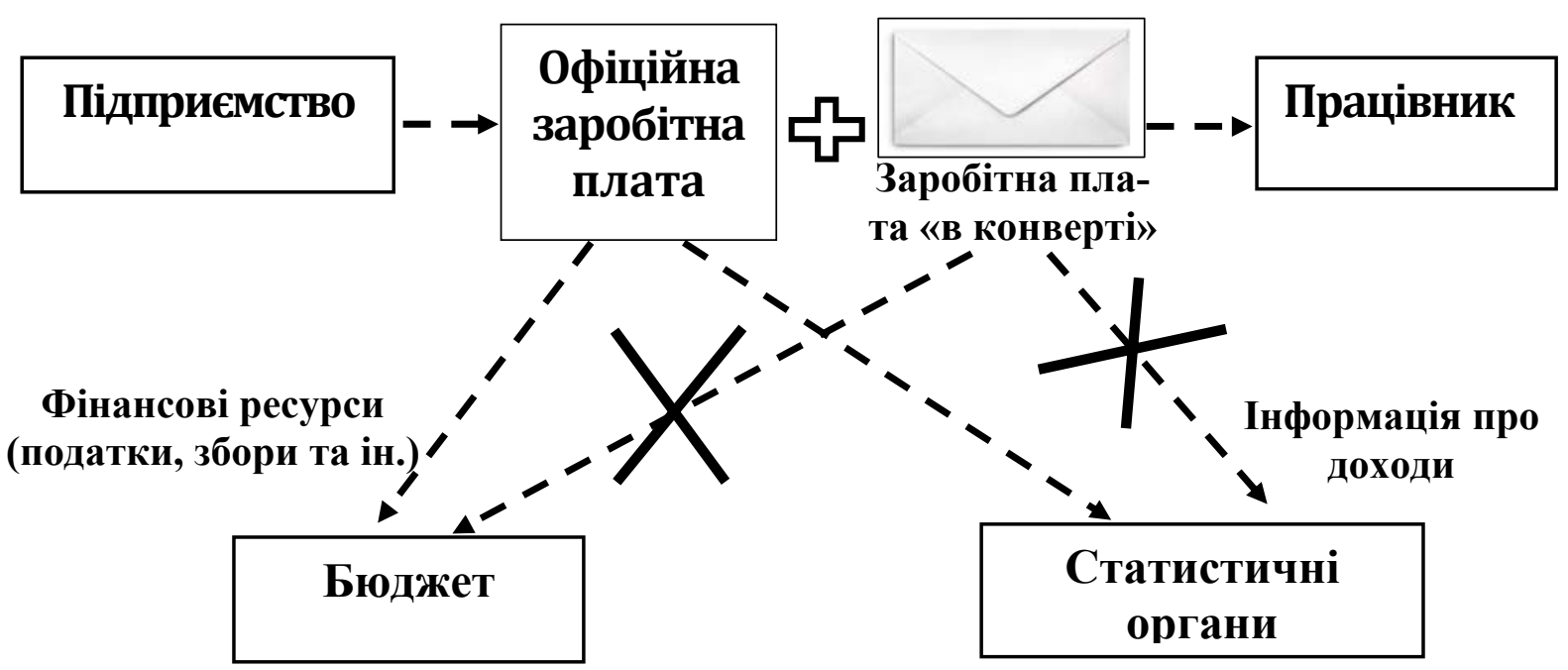

Рис. 2. Схема використання «сірої» заробітної плати

Джерело: власні дослідження 


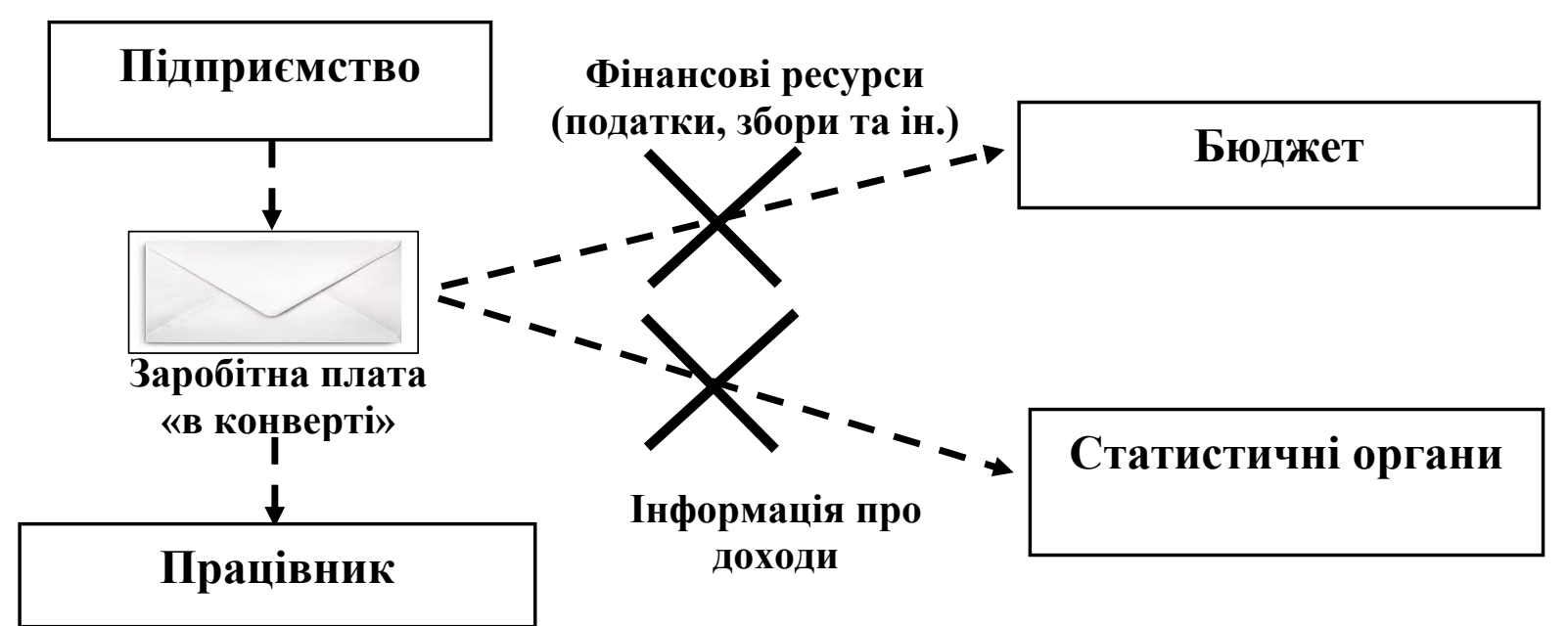

Рис. 3. Схема використання «чорної» заробітної плати

Джерело: власні дослідження

За бухгалтерськими документами робітник людина-невидимка, його не існує, а гроші, призначені на оплату праці, списуються під якісь інші витрати. Деякі бачать безліч зручностей у такій формі оплати: не треба возитися з паперами, оформлятися на роботу, платити податки. Але під час оформлення пенсії такий працівник здивується іiі розмірам, бо для держави він нероба, відрахувань до Пенсійного фонду від нього не надходило. Сума оплати його праці ніде не зафіксована. Якщо керівник вирішить переглянути усний договір в односторонньому порядку, відстояти свої права буде складно; відпустка й лікарняний залишаються виключно на совісті роботодавця; довідку з місця роботи не видадуть, про кредит можна забути.

За даними Незалежного фонду дослідження заробітних плат в Україні 27 \% працюючих громадян України залучено до «сірих» та «чорних» зарплатних схем. Водночас 9\% 3 них отримують «чорну» зарплату, тоді як $18 \%$ частину суми отримують офіційно. Крім того, більшість опитаних (83\%) знають про те, що зарплата «в конвертах» вплине на розмір майбутніх пенсій, а $12 \%$ опитаних просто не враховують такої небезпеки [2].

Відповідно до останнього дослідження Eurobarometer, частка зарплат «у конвертах» у 27 країнах ЄС коливається від $1 \%$ до $23 \%$. У середньому по Свросоюзу даний показник складає $5 \%$. Найбільш непрозора для влади система оплати праці зафіксована в найбіднішій країні Євросоюзу - Румунії, де майже кожна четверта зарплата (23\%) «вкладається в конверт». Далі йдуть нові члени $€ C$ і колишні країни соціалістичного блоку (Латвія, Болгарія, Литва, Польща, Естонія та Угорщина). 3-поміж країн Східної Європи середній показник $\mathrm{CC}$ не перевищують тільки Чехія і Словенія (3 і $5 \%$ ). Серед розвинених країн найвищий рівень «сірої» заробітної плати відзначений в Італії (7 \%) та Бельгії (6 \%) [9].

Використовуючи «чорну» й «сіру» заробітні плати, відбувається виникнення проявів тіньової економіки, що $є$ непростою задачею, оскільки будь-який учасник здатний проявляти прагнення до зміни умов домовленості на свою користь, як тільки інша сторона взяла на себе зобов'язання.

Очевидно, що нині основний тягар вини лежить «на плечах» підприємств, оскільки саме вони згідно з вітчизняним законодавством, а саме ст. 18 Податкового кодексу України, є податковими агентами, на яких «...покладається обов'язок $з$ обчислення, утримання з доходів, що нараховуються (виплачуються, надаються) платнику, та перерахування податків до відповідного бюджету від імені та за рахунок коштів платника податків» [8]. Отже, саме власники та директори підприємств повинні «потіснитися» своїми інтересами в системі взаємовідносин з метою забезпечення стійкого соціально-економічного розвитку.

Масштаби тіньової економіки не можуть не турбувати. Так, станом на 01.12.2014 року заборгованість роботодавців України перед найманими працівниками становила близько 2366,9 млн гривень [10]. Масовими залишаються випадки, коли працівникам підприємств-боржників не зараховується страховий стаж. Адже відомо, що згідно зі ст. 1 ЗУ «Про загальнообов'язкове державне пенсійне страхування» «страховий стаж період (строк), протягом якого особа підлягає загальнообов'язковому державному пенсійному страхуванню та, за який щомісяця сплачені стра- 


\section{СТОРІНКА МОЛОДОГО ВЧЕНОГО}

хові внески в сумі не меншій, ніж мінімальний страховий внесок» [3]. Внаслідок такої неналежної, злочинної діяльності вищого менеджменту підприємств страждають пересічні громадяни. I якщо міське населення є більш юридично обізнаним і проінформованим, може частково відстояти свої інтереси чи віддати перевагу іншому підприємству 3 кращими умовами праці, то сільське - недостатньо, крім того в них відсутня альтернатива вибору робочого місця, оскільки ринок праці на селі малий, а рівень безробіття високий.

Вважаємо, що тенденції масових виплат тіньової заробітної плати в Україні значною мірою $\epsilon$ суб'єктивно зумовленими. Адже за умисне ухилення від сплати єдиного внеску на загальнообов'язкове державне соціальне страхування, навіть у великих розмірах, державою згідно зі ст. 212-1 ККУ передбачено покарання лише у вигляді відносно невеликих штрафів [5]. Відзначимо, що частіше заборгованість існує у великих областях. Станом на 01.12.2014 року найбільше заборгували своїм працівникам суб'єкти господарювання Донецької області - 1056,9 млн грн, Луганської - 347,6 млн грн, Київської - 124,3 млн грн, Харківської - 123,8 млн грн. та Дніпропетровської - 101,5 млн грн [10]. Переважно це пов'язано з економічним станом у регіоні, чисельністю населення, кількістю підприємств і масштабом виробництва.

Необхідно зазначити, що нині органи влади не володіють повним комплектом інформації щодо заборгованості по заробітній платі. Саме тому такі дані досить часто різняться, що перешкоджає прийняттю оптимальних рішень, направлених на боротьбу з підприємствами-неплатниками. Така ситуація поширена зокрема в сільській міс- цевості. Частіше це пов'язано з сезонним характером робіт, коли працівників наймають на деякий проміжок часу. Підприємство офіційно сплачує своїм працівникам мінімальну заробітну плату, а решту вони отримують неофіційно «в конверті» [6].

Аналогічна ситуація щодо розвитку тіньової економіки спостерігається й під час отримання сільським населенням доходу від реалізації сільськогосподарської продукції, яка вирощується чи виробляється в особистих підсобних господарствах, що $є$ також вагомою часткою в структурі їх доходів. Адже переробні підприємства скуповують сировину за надзвичайно низькими цінами, які не забезпечують покриття витрат, понесених на їі виробництво, та не приносять очікуваного прибутку. Така ситуація призвела до швидкого розвитку виробництва в особистих господарствах, яке по окремих видах продукції стало переважаючим (плодоовочева група та молоко). Для багатьох сільських жителів є звичною реалізація залишків сільськогосподарської продукції, вирощеної на присадибній ділянці, а для значної кількості селян - це основне джерело доходу.

Реалізація сільськогосподарської продукції може здійснюватися за наступними каналами: 1) самостійний продаж на ринках; 2) через податкових агентів (закупівельним організаціям, переробним підприємствам, суб'єктам підприємницької діяльності, які займаються скуповуванням та реалізацією продукції, в т. ч. і без належного документального засвідчення операцій) (рис. 4).

Кошти, отримані від продажу, не відображаються в статистичній інформації як доходи, оскільки не мають ніякого офіційного підгрунтя.

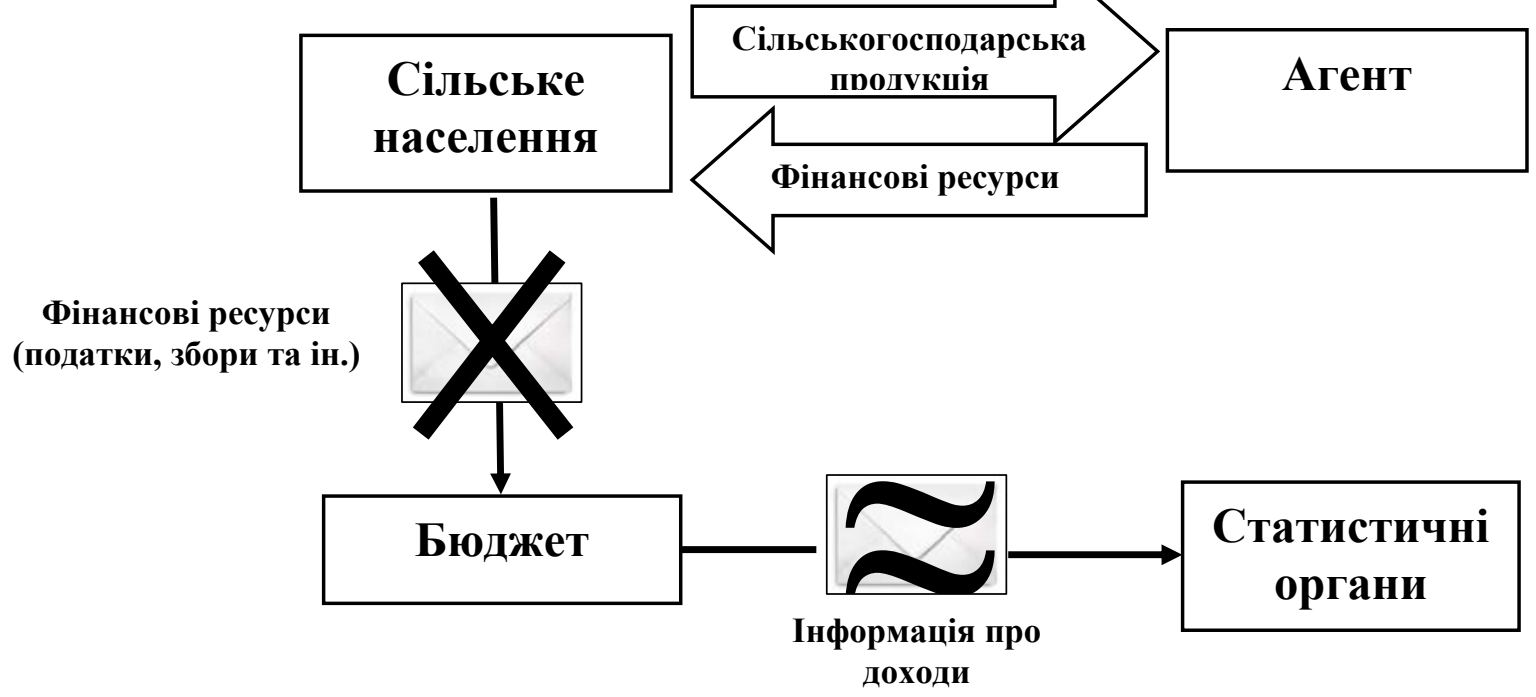

Рис. 4. Принципова модель підпільної економіки

Джерело: власні дослідження 


\section{СТОРІНКА МОЛОДОГО ВЧЕНОГО}

Проте упереджено ставитися до розвитку господарств населення та отримання ними таких тіньових доходів - рівнозначно грішити проти істини. Слід брати до уваги, що під час врахування оплати затраченої праці, продукція, вироблена в господарствах населення, є збитковою. Немає ніякої економічної підстави оподатковувати збитки. У підсобних господарствах без додаткових капітальних вкладень не допустили значного, як у сільськогосподарських підприємствах, спаду виробництва продукції. Якщо країні потрібна продукція цих господарств (а вона потрібна), то їх не слід оподатковувати, а навпаки, надати їм державну підтримку, як це робиться в Європейських країнах.

Економічна література, характеризуючи джерела формування доходів сільського населення, виокремлює первинні та вторинні. До першої групи належать заробітна плата та підприємницька діяльність, як такі, що є доходом активної частини населення. Відповідно такі надходження є оподаткованими й тому виконують роль наповнювачів бюджету. До другої групи - трансфертні платежі: пенсії, стипендії, субсидії, допомоги тощо; доходи від власності на капітал, землю, природні ресурси; продаж сільськогосподарської продукції: молочна та м'ясна продукція, яйця, мед, овочі, фрукти, ягоди, зерно, сіно, солома. Такі види доходів - вторинні, оскільки є додатковим джерелом одержання коштів, часто не систематичним, а їх одержувачі - неактивне населення (пенсіонери, безробітні, студенти тощо). Аналізуючи доходи сільського населення, виходячи зі специфіки галузі, пропонуємо виокремити ще одне джерело одержання доходів додаткові. Вони не включені в попередні групи через те, що їх практично неможливо відслідкувати, але досить часто вони є не просто додатковим, а хоч і тіньовим, але все ж основним джерелом доходу.

Сюди відноситься, по-перше, продаж свійських тварин та птиці (не на забій, а на подальше вигодовування чи використання у виробничій діяльності), оскільки вони не $є$ продукцією (ВРХ, свині, вівці, кози, коні, кури, качки, гуси, кролі тощо).

\section{БІБЛІОГРАФІЯ}

1. Авдийский В. И. Теневая экономика и экономическая безопасность государства : учеб. пособие / В. И. Авдийский, В. А. Дадалко. - [2-е изд., доп.]. - М. : Альфа-М, 2010. - 496 с.

2. Детінізація особистих доходів в Україні. Аналітична доповідь [Електронний ресурс]. Режим доступу : http://icps.com.ua/pub/files/35/56/
По-друге, продаж несільськогосподарської продукції (риба, гриби, упольовані тварини та птиця, деревина тощо). Досить часто, враховуючи місцевість, на якій проживає сільське населення (біля водойм, лісів), такий вид доходу відіграє провідну роль.

По-третє, надання послуг. У сільській місцевості можна виділити цілий спектр такого роду робіт: випасання худоби, ручний та механізований обробіток земельних ділянок, збір урожаю, сінозаготівля, обслуговування сільськогосподарської техніки, ветеринарні послуги, посередницький продаж ліків (за відсутності аптек), товарів народного промислу, організація «зеленого туризму» тощо.

Висновок. Отже, джерела доходів сільського населення, крім первинних і вторинних, різноманітні. Але тіньовий характер та відсутність офіційного відображення не дає повної інформації про їх рівень, що й відкриває перспективи для подальших досліджень.

Причинами поширення заробітної плати «в конвертах»є заниження фонду оплати праці, що спричинено надмірним рівнем податкового навантаження, нестабільністю законодавства, високим рівнем корупції.

Розв'язати проблему можливо шляхом використання дієвої системи боротьби 3 роботодавцями, що ведуть «тіньову» діяльність:

1) накласти значний економічний збиток у разі виявлення фактів «тінізації»;

2) посилити кримінальну відповідальність за економічні злочини та грубі порушення трудового законодавства.

Щодо продажу сільським населенням продукції, виробленої в особистих господарствах, то цю ситуацію потрібно врегулювати на державному рівні: контролювати рівень закупівельних цін на сільськогосподарську продукцію та зменшити податковий тиск на ii виробників, суб'єктів малого підприємництва.

Особисті підсобні господарства є власниками безцінного товару - землі, i тому держава має зробити ставку саме на їх підтримку, а оподаткування буде виступати лише механізмом контролю, а не перепоною сільського бізнесу.

Legal_green.doc.

3. Закон України «Про загальнообов'язкове державне пенсійне страхування» від 09.07.2003 № 1058-IV (зі змінами та доповненнями) [Електронний ресурс]. - Режим доступу : http:// zakon4.rada.gov.ua/laws/show/1058-15.

4. Кодекс законів про працю України 
від 10.12.1971 № 322-VIII [Електронний ресурс]. Режим доступу : http://zakon4.rada.gov.ua/laws/ show/ 322-08.

5. Кримінальний кодекс України від 05.04.2001 № 2341-III [Електронний ресурс]. - Режим доступу : http://zakon4.rada.gov.ua/laws/ show/234114.

6. Мороз О. В. Основні проблеми тінізації заробітної плати в Україні / О.В. Мороз, В. М. Семцов // Економіка АПК. - 2013. - №3. C. 94-101.

7. Мороз О. В. Тіньова економіка: структура, зміст та особливості функціонування / О. В. Мороз, В. М. Семцов // Економіка АПК. - 2013. №5. - С. 96-102.

8. Податковий кодекс України від 02.12.2010 № 2755-VI (зі змінами та доповненнями) [Електронний ресурс]. - Режим доступу : http:// zakon2.rada.gov.ua/laws/show/2755-17.

9. Служба вивчення громадської думки при Європейській комісії [Електронний ресурс]. Режим доступу : http:// ec/europa.eu/.

10. http://www.ukrstat.gov.ua/. 